\title{
Desain dan Pembuatan Prototype Piston Honda MEGAPRO FI Menggunakan 3D Printing
}

\author{
Frince Marbun ${ }^{1, *}$, Richard A. M. Napitupulu ${ }^{2}$ \\ ${ }^{1}$ Mahasiswa Prodi Teknik Mesin Universitas HKBP Nommensen, Medan-Indonesia \\ ${ }^{2}$ Dosen Prodi Teknik Mesin Universitas HKBP Nommensen, Medan-Indonesia \\ *princemarbunchen21@gmail.com
}

\begin{abstract}
3D printing technology has great potential in today's manufacturing world, one of its uses is in making miniatures or prototypes of a product such as a piston. One of the most famous and inexpensive $3 \mathrm{D}$ printing (additive manufacturing) technologies is Fused Deposition Modeling (FDM), the principle FDM works by thermoplastic extrusion through a hot nozzle at melting temperature then the product is made layer by layer. The two most commonly used materials are ABS and PLA so it is very important to know the accuracy of product dimensions. FDM 3D Printing Technology is able to make duplicate products accurately using PLA material. FDM machines work by printing parts that have been designed by computer-aided design (CAD) and then exported in the form of STL or .stl files and uploaded to the slicer program to govern the printing press according to the design. Using Anet A8 brand 3D printing tools that are available to the public, Slicing of general CAD geometry files such as autocad and solidwork is the basis for making this object. This software is very important to facilitate the design process to be printed. Some examples of software that can be downloaded and used free of charge such as Repetier-Host and Cura. by changing the parameters in the slicer software is very influential in the $3 \mathrm{D}$ printing manufacturing process.
\end{abstract}

Key words : 3D printing, additive manufacturing, FDM, STL, pistons

\section{PENDAHULUAN}

3D printing (additive manufacturing) merupakan suatu terobosan baru yang membawa perubahan besar dalam dunia teknologi modern [1]. Terobosan ini sangatlah populer di dunia [2], terutama di kalangan akademisi dan industri. 3D printing adalah proses pembuatan objek 3 dimensi dari produk yang digambar dengan gambar teknik di komputer dengan membuat material lapis demi lapis hingga membentuk objek yang diinginkan [3]. Teknologi 3D printing memiliki potensi yang besar dalam dunia manufaktur saat ini [4], salah satu penggunaannya adalah dalam membuat miniatur atau prototipe suatu produk.

Prototipe adalah sampel awal, contoh, model, atau rilis produk yang dibangun untuk menguji konsep. Prototipe umumnya digunakan untuk mengevaluasi desain baru yang akan menghasilkan produk jadi. Dalam pembuatan prototipe umumnya dengan cara tradisional seperti memahat, membubut, memotong, mengukir, menempa, dan lain sebagainya.

Agar prototipenya dapat dengan cepat dibuat, maka penggunaan 3D printing merupakan salah satu alternatifnya [5]. Dalam penelitian ini, penulis membuat prototipe Piston Honda Megapro FI. Honda Megapro merupakan jajaran produk motor sport dari Honda yang hadir dengan membawa beberapa perubahan khususnya pada sektor mesin dimana mesin motor Honda Megapro ini tergolong tangguh. Banyak digemari karena 
memiliki tenaga yang luar biasa dengan harga yang murah. Dalam membuat prototipe piston tersebut penulis tidak menggunakan cara yang tradisional melainkan menggunakan cara modern yakni dengan 3D printing.

\section{TINJAUAN PUSTAKA}

\subsection{Sistem Berbasis Ekstrusi}

Teknologi ekstrusi material dapat divisualisasikan seperti halnya icing kue, dimana material yang terkandung dalam reservoir dipaksa keluar melalui nosel saat tekanan diterapkan [6]. Jika tekanan tetap konstan, maka bahan ekstrusi yang dihasilkan akan mengalir dengan laju konstan dan akan tetap dengan diameter penampang yang konstan. Diameter ini akan tetap konstan jika perjalanan nozzle melintasi permukaan endapan juga dijaga pada kecepatan konstan yang sesuai dengan laju aliran. Bahan yang sedang diekstrusi harus dalam keadaan semi-padat ketika keluar dari nozzle. Bahan ini harus sepenuhnya dipadatkan dengan tetap dalam bentuk itu. Selanjutnya, bahan tersebut harus terikat pada bahan yang telah diekstrusi sehingga struktur yang solid dapat dihasilkan.

Karena bahan diekstrusi, mesin AM harus mampu memindai dalam bidang horizontal serta memulai dan menghentikan aliran bahan saat memindai. Ada pendekatan utama saat menggunakan proses ekstrusi. Pendekatan yang paling umum digunakan adalah menggunakan suhu sebagai cara mengendalikan keadaan material. Bahan cair dicairkan di dalam reservoir sehingga dapat mengalir keluar melalui nosel dan mengikat dengan bahan yang berdekatan sebelum memadat.

Ada sejumlah fitur utama yang umum untuk sistem berbasis ekstrusi:

1. Memuat material.

2. Pencairan material.

3. Ekstrusi.

4. Merencanakan berdasarkan jalur yang telah ditentukan dan dengan cara yang terkontrol.

5. Penyertaan struktur pendukung untuk mengaktifkan fitur geometris yang kompleks.

\subsection{Parameter Pada Percetakan 3D}

Parameter adalah salah satu referensi yang digunakan untuk mengatur nilai pada mesin untuk mendapatkan hasil yang diinginkan selama proses. Pada mesin cetak 3D, parameter dimasukkan melalui perangkat lunak slicer untuk menghasilkan bahasa pemrograman yaitu G-code, mesin akan membaca sebagai perintah untuk mencetak. Parameter yang terkandung dalam mesin cetak 3D adalah:

1. Tinggi lapisan adalah ketebalan setiap lapisan

2. Lebar ekstrusi adalah lebar material yang telah diekstrusi melalui nozzle. Nilai lebar ekstrusi harus lebih besar dari ketinggian layer.

3. Suhu nozzle adalah suhu yang berfungsi untuk memanaskan filamen menjadi bahan semi-padat.

4. Pola pengisian adalah pola pengisian inti objek. Mengisi inti objek hanya dapat dilakukan jika kepadatan isi kurang dari 100\%. Pola pengisi umumnya rectangular, line and honeycomb.

5. Fill density adalah nilai kerapatan isian pada inti objek. Nilai kerapatan isian berkisar antara $0-100 \%$. 
6. Bed temperature adalah suhu yang digunakan pada papan/pelat yang berfungsi sebagai tempat menempelkan bahan yang dihasilkan dari ekstrusi. Papan kontrol motor stepper.

7. Brim width adalah lapisan yang berfungsi untuk menambah lebih banyak perimeter ke lapisan pertama sebagai basis. Brim width digunakan untuk memberi lebih banyak area permukaan sehingga objek dapat menempel pada bed dan menjaga sudut cetak dari permukaan bed.

8. Speed adalah kecepatan saat proses mencetak suatu objek.

Pengaturan kecepatan default memiliki tiga kecepatan yang harus dipertimbangkan, termasuk:

\subsection{Bore dan Langkah Piston}

Berdasarkan Bore atau diameter silinder (D) dan panjang langkah torak (s), menjadi tiga tipe :

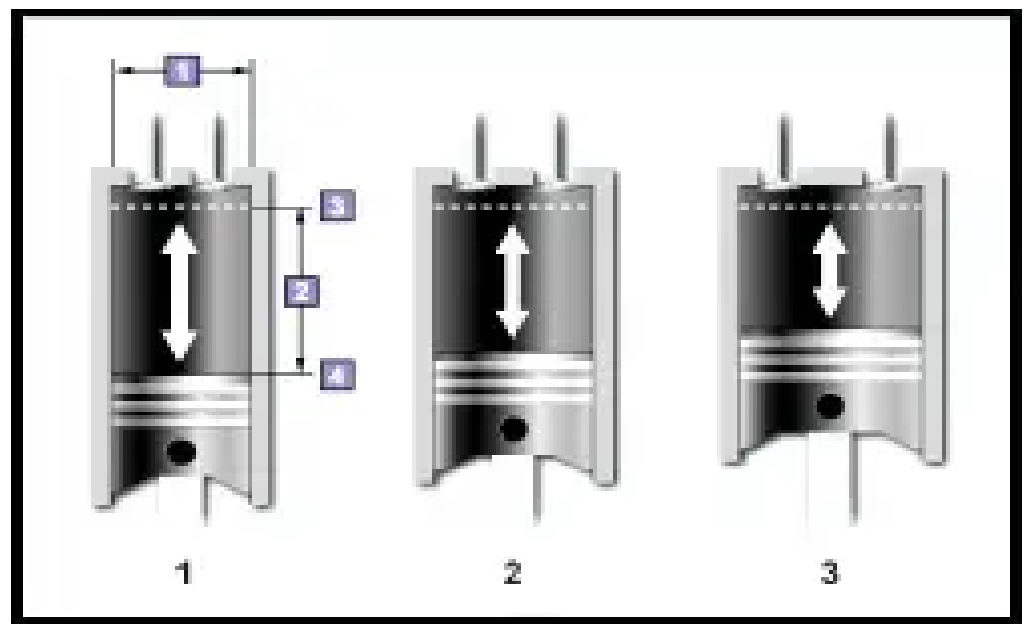

Gambar 1. Tipe Motor

1. Motor dengan long-stroke

Motor dimana langkah torak lebih besar dari silinder bore.

2. Motor persegi (mesin persegi)

Motor dimana bore dan langkah torak memiliki ukuran yang sama.

3. Motor dengan stroke pendek

Motor dimana langkah torak lebih kecil daripada silinder bore.

\section{METODOLOGI}

\subsection{Bahan}

Bahan yang digunakan untuk merancang dan pembuatan prototipe Piston Honda Megapro adalah sebagai berikut.

1. Filamen PLA

2. ArusListrik

3. Kepala Piston

4. BatangPison

5. Pin Piston

\subsection{Peralatan Yang Digunakan Untuk Pembuatan Prototipe}

1. Komputer atau Laptop

Berfungsi untuk mengambar objek yang dirancang. 
2. Mesin 3D printing

Berfungsi untuk mencetak objek yang digambar

3. Gunting

Berfungsi untuk memotong filamen

4. Kertas Pasir

Berfungsi untuk pengamplasan

5. Mistar dan Jangka Sorong

Berfungsi untuk alat ukur benda yang ingin digambar

6. Waterpass

Berfungsi untuk mengukur ke dataran build plate

\subsection{Prototipe yang Dirancang}

1. Kepala Piston

2. Batang Piston

3. Pin Piston

\subsection{Gambar Komponen Perancangan}

Dalam penelitian ini, komponen yang digambar mengikuti ukuran dan dimensi kepala piston, batang piston dan pin piston yang telah jadi.

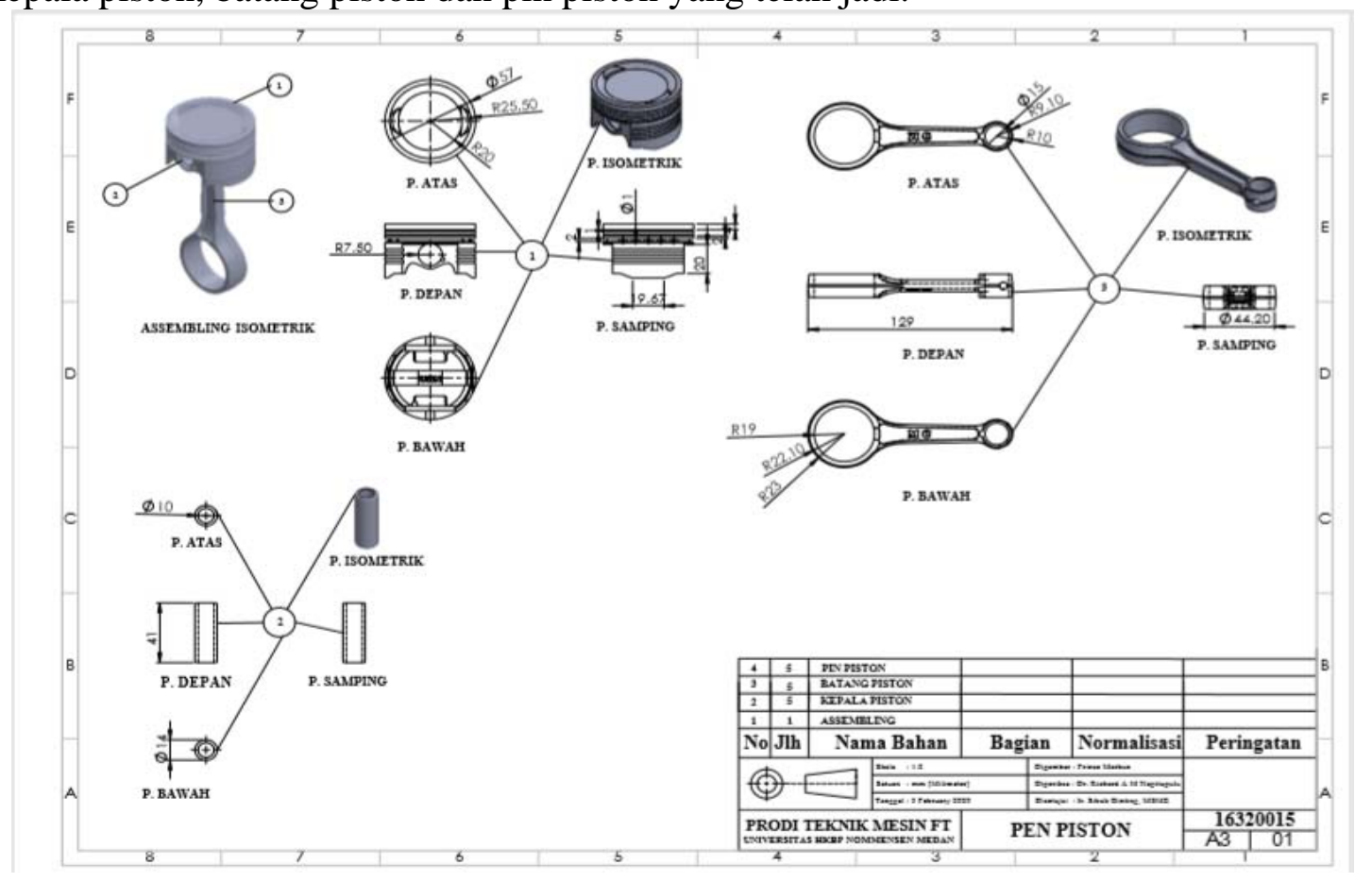

Gambar 2. Gambar teknik piston

\section{Parameter Printing Prototype}

\subsection{Kepala Piston}

Percobaan I 


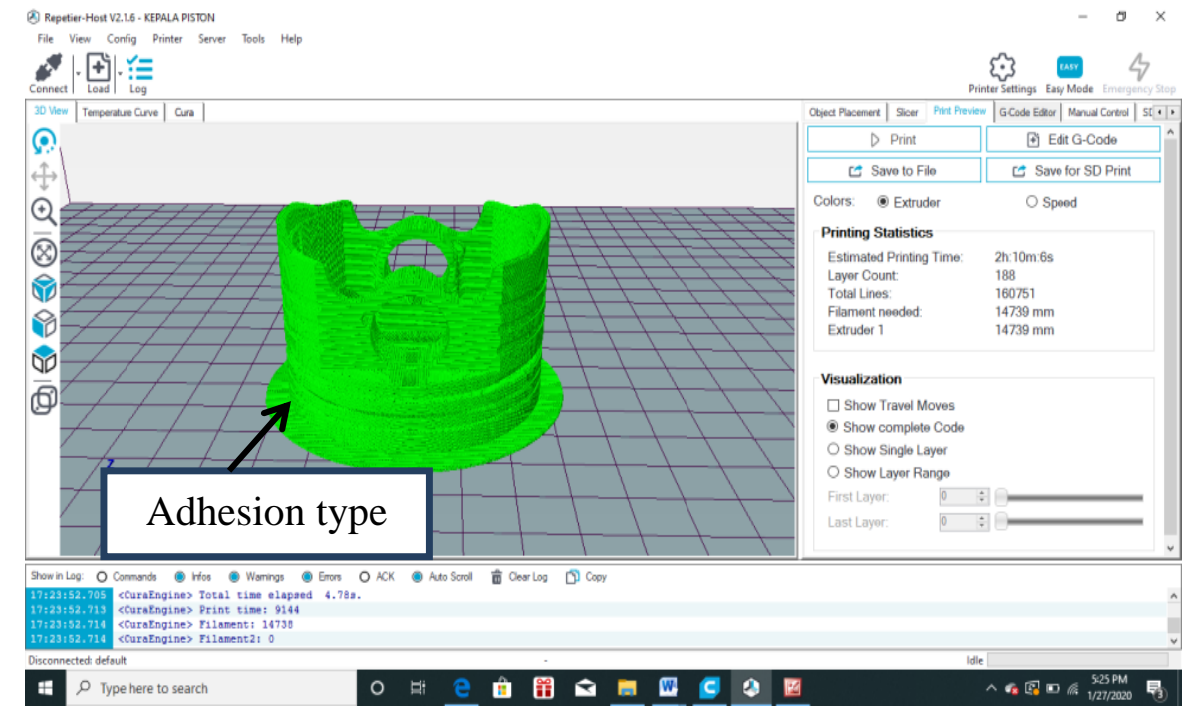

Gambar 3. Kepala piston posisi permukaan atas bertumpu ke bed

a. Settingan Parameter :
1. Slicer
: Repetier-Host / Cura
2. Nozzle
$: 0.2$
3. Profil
$: 0.2$
4. Adhesion type
: Raft
5. Support type
: Touching Bed
6. Infill
: $40 \%$
7. Infill patern
: Grid
8. Top/bottonthicknes
$: 4$
9. Speed
: $80 \mathrm{~mm} / \mathrm{s}$
10. Infill support
: $25 \%$
11. Printing temperature
$: 190$
12. Bed temperature
: 50

b. Printing Statistic
1. Estimate printing time
: 2h : 10m: 6s
2. Layer count
: 188
3. Total lines
: 160751
4. Filament
: $14739 \mathrm{~mm}$
5. Weight
: $29 \mathrm{~g}$

Disini penulis mengambil posisi tegak, dengan posisi pada gambar 3 seperti ini akan menghasilkan permukaan atas objek yang lebih halus/bagus dibandingkan dengan posisi objek bagian atas berada di bawah. Posisi ini tidak memerlukan banyak support, hanya bagian yang berhadapan langsung dengan meja yang di support. 
Percobaaan II

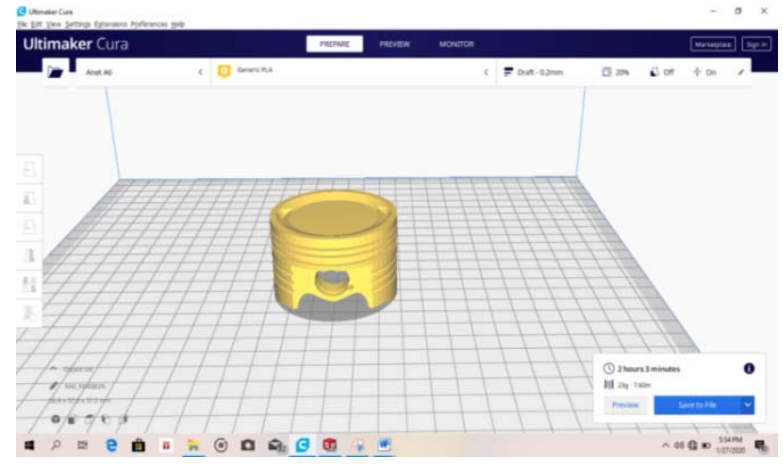

Gambar 4. Kepala piston posisi permukaan bawah bertumpu ke meja

a. Settingan Parameter :
1. Slicer
: Ultimaker Cura
9. Speed
: $75 \mathrm{~mm} / \mathrm{s}$
2. Nozzle
: 0.4
10. Infill support : $25 \%$
3. Profil
: 0.2
11. Printing temp. : 190
4. Adhesion type
: Raft
12. Bed temperature : 50
5. Support type
: Touching bed
: $40 \%$
6. Infill
: Line
7. Infill patern
$: 4$

b. Printing Statistic
1. Estimate printing time
$: 2 \mathrm{~h}: 30 \mathrm{~m}$
4. Filament : $17877 \mathrm{~mm}$
2. Layer count
$: 188$
3. Total lines
: 165167
5. Weight : 29 gr

Pada gambar 4 posisi ini akan memerlukan banyak support mulai dari bagian bawah objek sampai bagian tengah objek yang menutupi objek aslinya. Namun support-support yang menempel pada objek tersebut sangat mudah dilepas/ dibersihkan dikarenakan pengaturan parameter support yang baik/cocok pada proses slicing di ultimaker cura.

\subsection{Batang Piston}

\subsubsection{Percobaan Pertama}

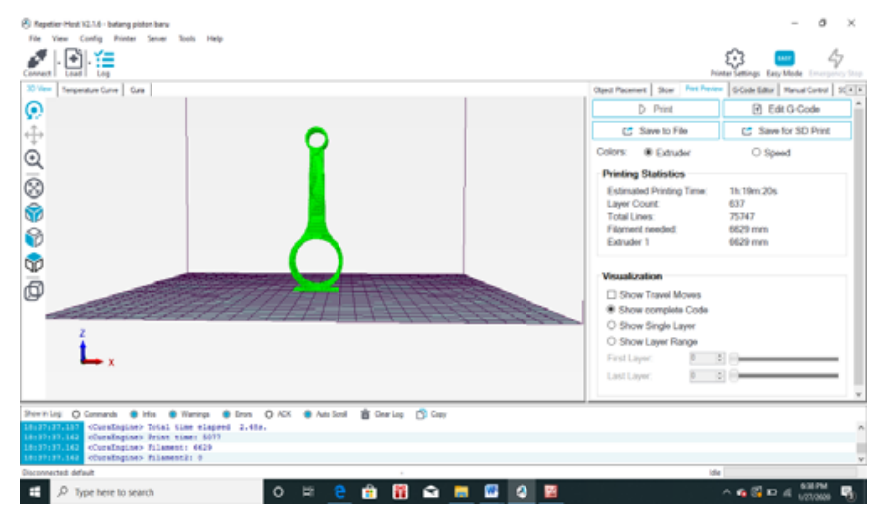

Gambar 5. Kepala piston posisi vertikal

Pada gambar 5, posisi batang piston yang digambar dibuat tegak dengan support touching bed. Pemilihan profil atau ukuran nozzle juga sangat berpengaruh kepada 
produk hasil printer. Ukuran nozzle yang banyak dijual di pasaran adalah 0.2, 0.3, 0.4, 0.6, 0.8, 1.0 (mm). Semakin kecil ukuran nozzle yang digunakan semakin bagus dan halus produk hasil printer dan harus disesuaikan dengan settingan parameter slicer. Pemakain nozzle baru hasilnya akan lebih bagus berbeda dengan nozzle yang sudah lama meskipun dengan ukuran yang sama.

a. Settingan Parameter :
1. Slicer
: Repetier-Host/ Cura
2. Nozzle
$: 0.2$
3. Profil
$: 0.2$
4. Adhesion type
:Raft
5. Support type
: Touching bed
6. Infill
: $35 \%$
7. Infill patern
: Grid
8. Top/bottonthicknes
$: 4$
9. Speed
: $75 \mathrm{~mm} / \mathrm{s}$
10. Infill support
: $25 \%$
11. Printing temperature : 190
12. Bed temperature : 50

b. Printing Statistic
1. Estimate printing time
: 1h : 19m: 20s
4. Filament $: 6629 \mathrm{~mm}$
2. Layer count
: 674
5. Weight : $12 \mathrm{~g}$
3. Total lines
: 75747

4.2.2. Percobaaan II

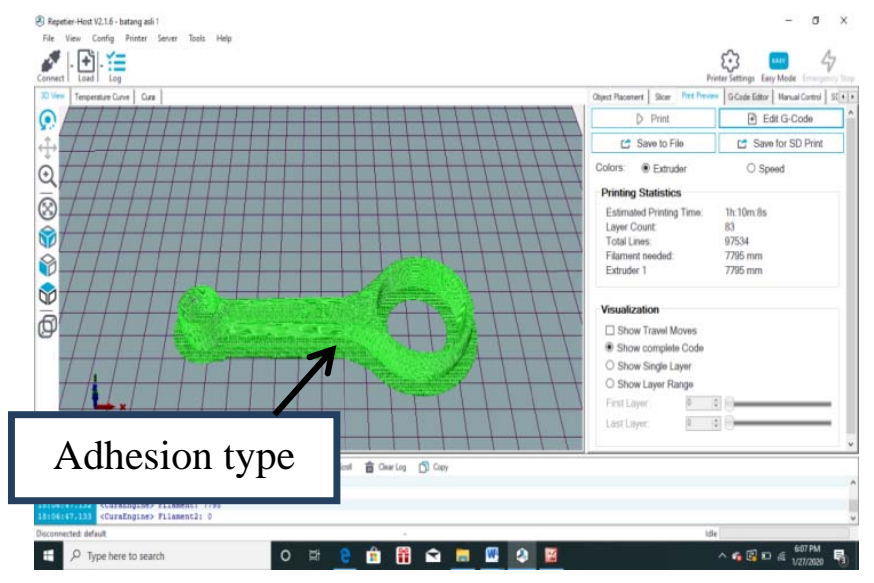

Gambar 6. Kepala piston posisi horizontal

a. Settingan Parameter :
1. Slicer
: Repetier-Host/Cura
2. Nozlle
$: 0.2$
3. Profil
$: 0.2$
4. Adhesion type
: Raft
5. Support type
: Touching bed
6. Infill
: $40 \%$ 

7. Infill patern
: Grid
8. Top/bottonthicknes : 4
9. Speed
: $75 \mathrm{~mm} / \mathrm{s}$
10. Infill support
: $25 \%$
11. Printing temperature : 190
12. Bed temperature $\quad: 50$

b. Printing Statistic
1. Estimate printing time
$: 1 \mathrm{~h}: 10 \mathrm{~m}: 8 \mathrm{~s}$
4. Filament $: 7795 \mathrm{~mm}$
2. Layer count
: 83
5. Weight : $12 \mathrm{gr}$
3. Total lines
: 97534

Pada gambar 6, posisi dibuat horizontal untuk mendapatkan lubang atau lingkaran pada batang piston bulat utuh dengan bantuan settingan parameter di atas.

\subsection{Pin Piston}

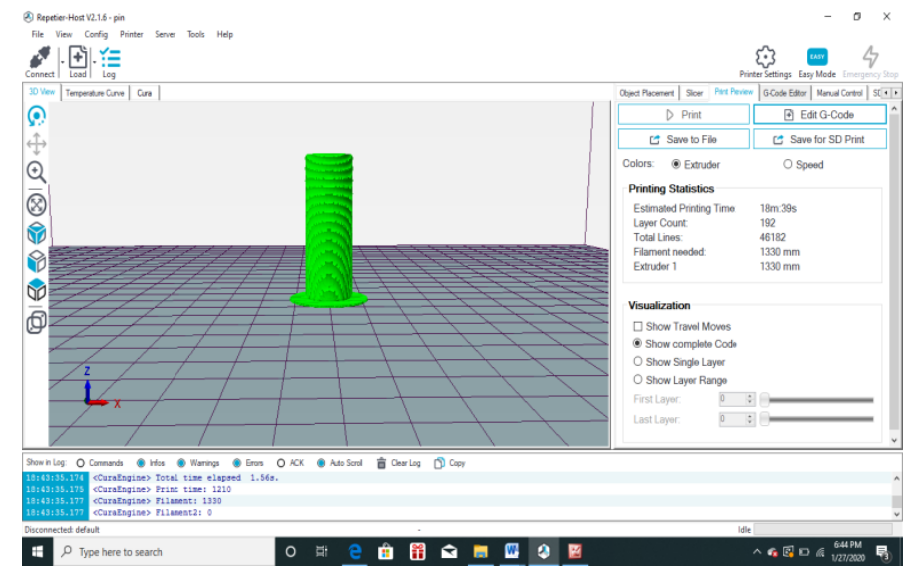

Gambar 7. Pin piston posisi vertical

a. Settingan Parameter :
1. Slicer
: Repetier-Host /Cura
2. Nozlle
$: 0.2$
3. Profil
$: 0.2$
4. Adhesion type
: Raft
5. Infill
: $40 \%$
6. Infill patern
: Grid
7. Top/bottonthicknes
$: 4$
8. Speed
: $75 \mathrm{~mm} / \mathrm{s}$
9. Printing temperature
: 190
10. Bed temperatur
: 50

b. Printing Statistic
1. Estimate printing time
: 18m: 38s
2. Layer count
: 192
3. Total lines
: 46182
4. Filament
: $1330 \mathrm{~mm}$
5. Weight
$: 4 \mathrm{~g}$ 
Karena pin piston berbentuk tabung maka untuk tahap slicing pin piston dibuat horizontal menghindari kegagalan dalam proses manufaktur seperti pada gambar 7 .

Tabel 1. Parameter waktu proses manufaktur Printer 3D

\begin{tabular}{|c|c|c|c|c|}
\hline No. & Desain & Posisi & Support & Waktu \\
\hline 1 & Kepala piston I & Vertical & Touching Bed & $2 \mathrm{~h}: 10 \mathrm{~m}: 6 \mathrm{~s}$ \\
\hline 2 & Kepala Piston II & Vertical & Touching Bed & $2 \mathrm{~h}: 30 \mathrm{~m}: 11 \mathrm{~s}$ \\
\hline 3 & Batang piston I & Vertical & Touching Bed & $1 \mathrm{~h}: 19 \mathrm{~m}: 20 \mathrm{~s}$ \\
\hline 4 & Batang piston II & Horizontal & Toching Bed & $1 \mathrm{~h}: 10 \mathrm{~m}: 6 \mathrm{~S}$ \\
\hline 5 & Pin piston & Vertical & - & $18 \mathrm{~m}: 8 \mathrm{~s}$ \\
\hline
\end{tabular}

\section{HASIL PRINTING 3D}

\subsection{Kepala piston}
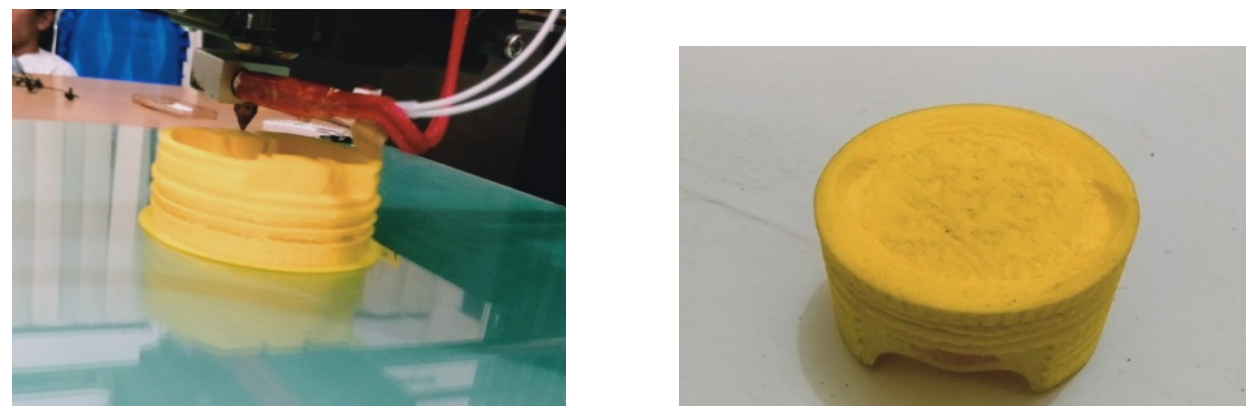

Gambar 8. Hasil manufaktur kepala piston percobaan pertama

Pada gambar 8, permukaan yang disupport atau bagian atas kepala piston hasilnya tidak bagus, banyak kerusakan yang terjadi yaitu permukaan yang begitu kasar. Tempat ring kepala piston juga tidak bagus atau gagal.

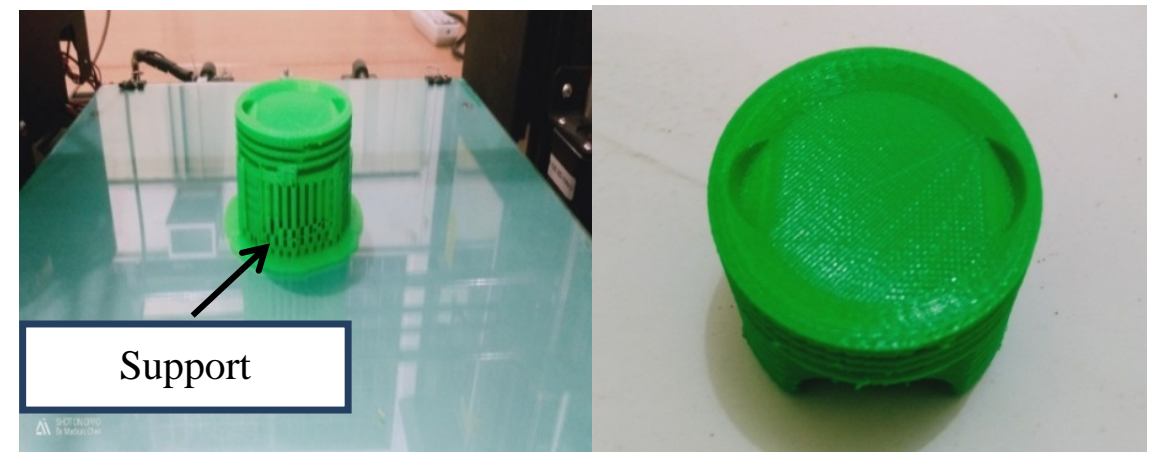

Gambar 9. Hasil manufaktur kepala piston percobaan ke dua

Setelah melihat kegagalan pada gambar 8, untuk mendapatkan permukaan atas kepala piston yang halus maka slicing kepala piston dibuat seperti gambar 4.7 meskipun memerlukan support yang begitu banyak dan memerlukan waktu yang lama serta menghabiskan filament yang begitu banyak dibandingkan percobaan pertama. 


\subsection{Batang Piston}

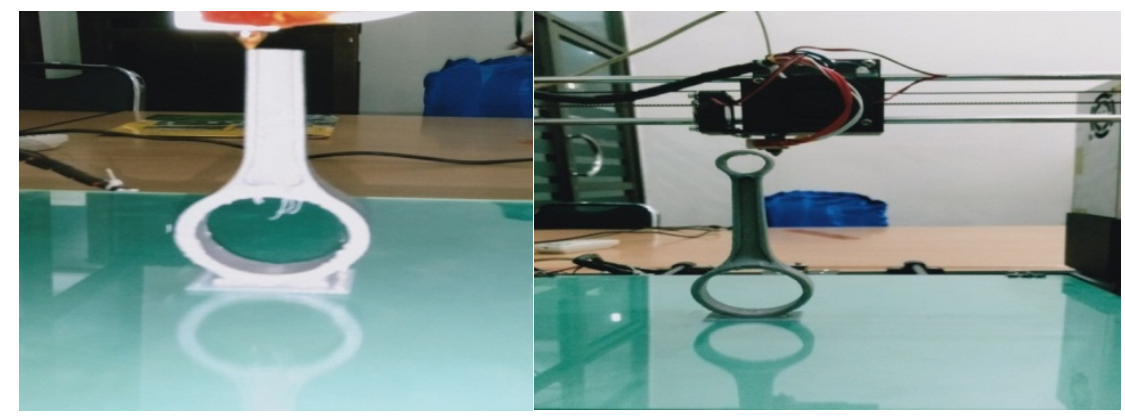

Gambar 10. Hasil batang piston vertikal

Pada gambar 10, batang piston tepatnya pada lubang big pin mengalami kerusakan atau tidak bulatnya lubang tersebut karena posisi tersebut membuat lubang mengalami tekanan sehingga membuatnya tertekan dan terdefleksi.

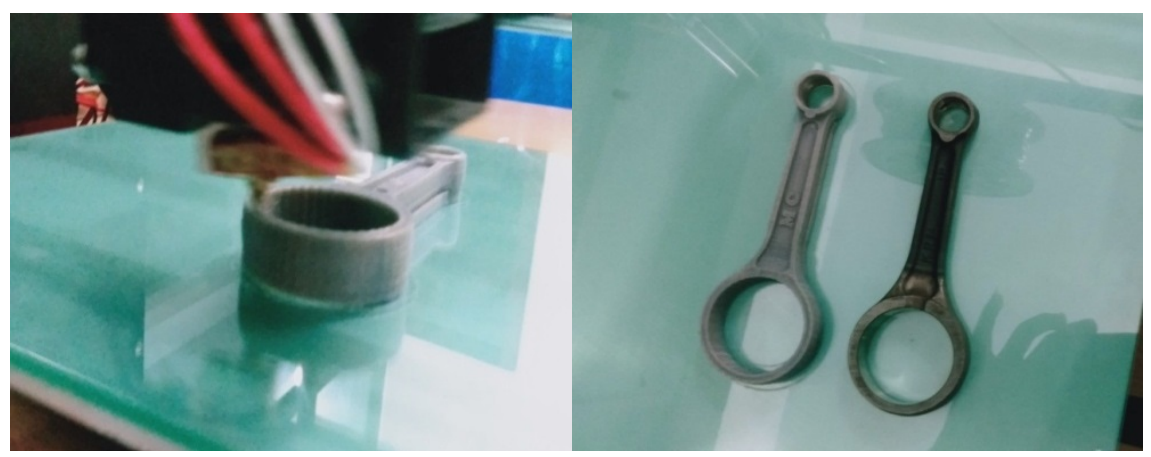

Gambar 11. Hasil batang piston horizontal

Hasil pada gambar 11 lumayan bagus hanya ada sedikit kekasaran di bagian permukaan yang disupport.

\subsection{Pin piston}

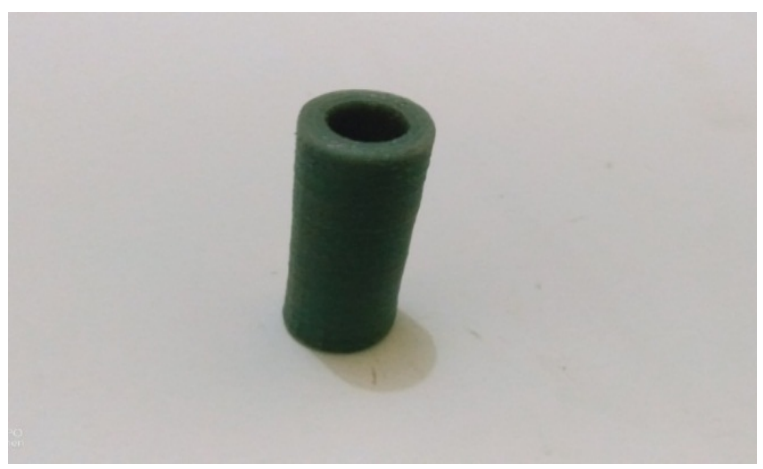

Gambar 12. Pin piston posisi vertikal

Slicing pin piston tidak memerlukan support, hanya menggunakan adhesion type untuk menjaga pin piston tetap lengket di bed selagi dalam proses manufaktur seperti pada gambar 12 . 


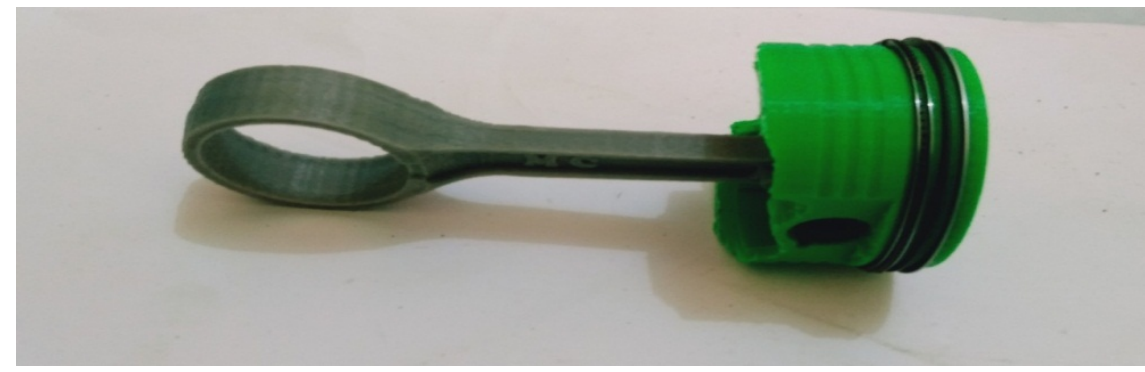

Gambar 13. Hasil finishing setelah diassembly

Setelah selesai dibersihkan selanjutnya benda yang dibuat disassembly untuk mengetahui apakah hasilnya sesuai ukuran seperti pada gambar 13.

Dalam hal waktu printer menyelesaikan produk tidak sama dengan hasil dari aplikasi slicer. Penulis menemukan bahwa, kadang printer membutuhkan waktu yang sudah tertera dalam aplikasi bertambah sekitar 60\% sampai 70\% dari waktu yang ada di aplikasi.

\section{KESIMPULAN}

Setelah dilakukan pengujian dan penelitian dapat disimpulkan bahwa :

1. Mesin 3D printing tipe FDM mampu membuat prototype Piston Honda Mengapro F1 meskipun tidak begitu bagus dan ada beberapa kekurangan.

2. Mesin 3D printing yang digunakan belum mampu untuk membuat suatu produk dengan tingkat ketelitian yang tinggi dan produk yang dihasilkan tidak rapat dan tidak halus.

3. Proses finishing memerlukan kertas pasir untuk menghaluskan permukaan yang disupport.

4. Ukuran nozzle sangat berpengaruh dimana semakin kecil profil atau ukuran lubang nozzle maka semakin bagus dan halus hasil yang print dan settingan parameter slicing harus sesuai dengan nozzle.

5. Pemilihan infill tergantung pada ukuran produk. Persentase infill yang digunakan sekitar 20\% sampai 60\% untuk menghindari printer yang mengeluarkan filamen yang berlebihan saat sedang membuat produk.

\section{DAFTAR PUSTAKA}

1. Gebhardt, Hötter, Additive Manufacturing, Hanser, Munich, 2016.

2. Gibson, Ian, Additive Manufacturing Technologies, second ed., Springer, New York, 2015.

3. Wohlers TT (2014) Wohlers report 2014: additive manufacturing and 3D printing state of the industry: annual worldwide progress report. Fort Collins, Wohlers Associates.

4. Joan Horvath, Mastering 3D Printing, Pasadena, California, 2014.

5. H.Bikas. P.Stavropoulus. G.Chyssolouris, Additive manufacturing methods and modeling approaches : a critical review, Int J Adv Manuf Technol (2016) 83:389405.

6. Chu Yin Huang. Extrusion-based 3D Printing and Characterization of Edible Materials. Waterloo, Ontario, Canada.2018. 